Original Article

\title{
SCREENING OF PHYTOCHEMICAL, ANTIOXIDANT ACTIVITY AND ANTI-BACTERIAL ACTIVITY OF MARINE SEAWEEDS
}

\author{
RAJASEKAR T. ${ }^{*}$, MARY SHAMYA A., JERRINE JOSEPH
}

Centre for Drug Discovery and Development, Col. Dr. Jeppiaar Research, Park, Sathyabama Institute of Science and Technology (Deemed University), Chennai 600119

*Email: microraja09@gmail.com

Received: 14 Aug 2018 Revised and Accepted: 23 Nov 2018

\begin{abstract}
Objective: Phytochemical is naturally present in the seaweeds which biologically play a significant role. The intention of this study was designed to screen the phytochemical constituents and antimicrobial potential of selected seaweed collected from Rameshwaram and Tuticorin Southern coast of India.

Methods: The present study investigated the presence of phytochemical constituents and also total phenol, total carbohydrate and total protein quantity of the brown seaweed. Dictyopteris delicatula, Padina gymnospora, Acanthophora spicifera, Portieria hornemannii and Ulva faciata were extracted with solvents having different polarities like methanol, ethanol, chloroform and water and screened for the phytochemical constituents, total phenol, total carbohydrate, total protein and DPPH with standard procedure. The antibacterial activities of the seaweeds were examined by agar well diffusion method.
\end{abstract}

Results: Among the five seaweeds, $U$. faciata showed the maximum number of active constituents in the methanol extract likewise $P$. gymnospora was found to have a number of diligent compounds in ethanol extract. A. spicifera showed minimum compounds in ethanol as well as chloroform extract. Moreover A. spicifera, P. hornemannii have shown the superior quantity of protein and carbohydrate when compared to other species. The scavenging activity of methanol extracts at $5 \mathrm{mg} / \mathrm{ml}$ concentration $P$. hornemannii shows $18.2 \%$ and $A$. spicifera possess $17.1 \%$. In the antibacterial activity, methanol extracts of all the seaweed showed a potential inhibitory activity against B. cereus and $P$. aeruginosa compared to other pathogens.

Conclusion: The crude extract of seaweed manifest preferable antimicrobial and antioxidant activities, hence in the future, it would be good if it is further taken for treatment of human diseases or as new antimicrobial agents to replace synthetic antimicrobial agents.

Keywords: Seaweed, DPPH, Protein, Carbohydrate, Dictyopteris delicatula, Padina gymnospora, Acanthophora spicifera, Portieria hornemannii, Ulva faciata

(C) 2019 The Authors. Published by Innovare Academic Sciences Pvt Ltd. This is an open access article under the CC BY license (http://creativecommons.org/licenses/by/4.0/) DOI: http://dx.doi.org/10.22159/ijpps.2019v11i1.29119

\section{INTRODUCTION}

Seaweed is a common name of marine algae, a group of species from the Protista kingdom, meaning they are not plants at all, even though they may look like underwater plants. They have therapeutic and nutritive properties as innovative, inventive sources of natural products. The bioactive compound obtained from this seaweed is having a unique structure and activity [1]. Most of the seaweed we consume is as food, feed, and fertilizer in many parts of the world. They constitute a vital part of marine ecosystems. These seaweeds are reservoirs of pigments, Polyphenols, enzymes, carotenoids, diverse functional polysaccharides [2-3]. They have a good source of vitamin A, B1, B12, D, C and E. These seaweeds are potential reservoirs of bioactive compounds, which might be a potential source of nutrients [4]. Today seaweeds are the raw material for industrial production of agar, alginic acid, and carrageenan, but they continue to be widely consumed as food in Asian countries [5]. Algal phytochemical extracts are used in various industries such as food, confectionery, textile, pharmaceutical, dairy and paper, mostly as gelling, stabilizing and thickening agents. They are living, renewable resources and may also a good source of protein, polysaccharides and fibers in addition of vitamins and minerals [6-7]. A wide range of studies has described the high antioxidant capacity of a range of edible seaweeds. This capacity is endowed by the presence of sulfated polysaccharides, Polyphenolic compounds and antioxidant enzymes. Oxidative stress may play a key role in the development of cancers and cardiovascular disease. Brominated phenols, oxygen heterocyclics, nitrogen heterocyclics, sulfur-nitrogen heterocyclics, sterols, terpenoids, polysaccharides, peptides, proteins, halogenated ketone, alkanes, and cyclic polysulfides are generally present in the seaweed as photochemical compounds [8]. These stunning medicinal properties comprise antibacterial, antifungal, antiprotozoal, antifertility, antiviral, anticancer and antimalarial activities [9-11]. Even hundreds of biologically active compounds are discovered till now. But the unique therapeutic compounds are needed for the upcoming diseases and drug-resistant microorganisms [12]. The phytochemical research approach is considered effective in discovering bioactive profile of the marine algae of therapeutic importance. The present study investigated the presence of phytochemical constituents and also total phenol, total carbohydrate and total protein quantity of the brown seaweed $D$. delicatula, $P$. gymnospora red seaweed A. specifera, $P$. hornemannii and green seaweed Ulva faciata.

\section{MATERIALS AND METHODS}

\section{Chemical required}

Alcoholic sodium hydroxide, distilled water, concentrated sulphuric acid, 1\% aqueous iron chloride, acetic anhydride, sulphuric acid, glacial acetic acid, chloroform, sodium hydroxide, hydrochloric acid, ammonia, Bradford reagent, aqueous ferric chloride, copper sulphate.

\section{Sample collection}

The seaweeds were collected from Mandapam, Rameshwaram and Tuticorin Southern coast of India. It is authenticated by Dr. Anantharaman, Associate Professor, CAS Marine Biology, Parangipettai and Annamalai University. The collected sample was washed well with seawater to remove all the extraneous impurities such as epithets, sand particles, pebbles, and shells and brought to the laboratory in plastic bags aseptically in ice boxes. The samples were then thoroughly washed with tap water followed by distilled water. Washed seaweeds were blotted on the blotting paper, shade 
dried at ambient temperature and the samples were grounded into a fine powder using tissue blender. The powdered samples were then stored in the refrigerator for further use. The classifications of seaweed are shown in table 1.

Table 1: Classification seaweeds

\begin{tabular}{|c|c|c|c|c|c|}
\hline Seaweed & Kingdom & Order & Family & Genus & Species \\
\hline Brown Seaweed & Chromista & Dictyotales & Dictyotaceae & $\begin{array}{l}\text { Dictyopteris } \\
\text { Padina }\end{array}$ & $\begin{array}{l}\text { D. delicatula, } \\
\text { P. gymnospora }\end{array}$ \\
\hline Red Seaweed & Plantae & Ceramiales & Rhodomelaceae & $\begin{array}{l}\text { Acanthophora } \\
\text { Portieria }\end{array}$ & $\begin{array}{l}\text { A. spicifera } \\
\text { P. hornemannii }\end{array}$ \\
\hline Green Seaweed & Plantae & Ulvales & Ulvaceae & Ulva & U. fasciata \\
\hline
\end{tabular}

\section{Preparation of seaweed extracts}

Ten grams of powdered samples were packed in Soxhlet apparatus and extracted with (1:10) solvents like methanol, chloroform, and ethanol and aqueous for $8 \mathrm{~h}$, and the filtrate was collected (crude extracts) and stored in the refrigerator until further use.

\section{Phytochemical analysis}

To detect the presence of following biomolecules by standard qualitative phytochemical procedures [13-14]. Test for alkaloids using Mayer's reagent, for tannins using ferric chloride, flavonoids using ammonia, for glycosides with chloroform and $10 \%$ ammonium solution [15]. Saponins test done by distilled water with vigorous shaking [16], the presence of terpenoid confirmed with chloroform and sulfuric acid [17]. Phlobatanin, steroids, cardiac glycoside, phenols, quinones, carbohydrate, protein, betacyanin, and coumarin are also tested with standard procedures.

\section{Antimicrobial activity test}

The antimicrobial activity extracts tested against five pathogenic bacteria Bacillus cereus, Escherichia coli, Pseudomonas aeruginosa, Candida albicans, Staphylococcus aureus (obtained from the Medical Microbiology Laboratory, Periyar University, Salem, Tamil Nadu) by the Agar well diffusion method. Briefly, the Medium was prepared using Muller Hinton Agar Medium (HiMedia) in distilled water and autoclaved. The autoclaved medium was mixed well and poured onto $100 \mathrm{~mm}$ Petri plates $(25-30 \mathrm{ml} /$ plate $)$ while still molten. The Muller Hinton medium was seeded with the $24 \mathrm{hr}$ culture of bacterial strains. Wells were cut, and $100 \mu \mathrm{l}$ of the methanol extract stock (10 $\mathrm{mg} / \mathrm{ml}$ ) was added. The plates were then incubated at $37^{\circ} \mathrm{C}$ for 12 to $24 \mathrm{~h}$. The antibacterial activity was assayed by measuring the diameter of the inhibition zone formed around the well [18]. The experiments were implemented in triplicates, and the mean \pm values were calculated and tabulated [19].

\section{Antioxidant activity-DPPH method}

Free radical scavenging inhibition assay it is used to determine the antioxidant capacity of the methanol extract of seaweed [20]. DPPH was prepared in ethanol and it has to be prepared freshly and used. Add $1 \mathrm{ml}$ of methanol extract of seaweed sample in this $1 \mathrm{ml}$ of DPPH solution were added it was incubated for about $30 \mathrm{~min}$ in a dark condition and the decrease in absorbance was monitored at $517 \mathrm{~nm}$ in UV-VIS spectrophotometer (UV-Shimadzu UV 1800). Ascorbic acid is used as a standard. The percentage of inhibition was calculated as

$$
A A \%=100-\left\lceil\frac{\left(A b s_{\text {sample }}-A b s_{\text {blank }}\right) x 100}{A b s_{\text {control }}}\right\rceil
$$

\section{Total phenol content}

According to Wang et al. 2013 [21] total phenol content has been determined. $1 \mathrm{ml}$ of seaweed extract was mixed with $1 \mathrm{ml}$ of diluted 1:10 Folin-Ciocalteau reagent and $1 \mathrm{ml} 20 \%, \mathrm{w} / \mathrm{v}$ sodium bicarbonate were added. And the solutions are kept at room temperature for about $30 \mathrm{~min}$ and the reading has been taken at $735 \mathrm{NM}$ by UV-VIS spectrophotometer (UV3100PC, VWR International). Results were expressed as mg Phloroglucinol equivalents (PGE)/gdb.

\section{Sulfate content}

It involves acid hydrolysis of the sample followed by the determination of inorganic sulfate by turbid metric method [22]. After acid hydrolysis $0.2 \mathrm{ml}$ of sample with $3.8 \mathrm{ml}$ of $3 \%$ Trichloroacetic acid into this adds $1 \mathrm{ml}$ of barium chloride-gelatin reagent was added and mixed well. Then it was incubated at room temperature for about $15 \mathrm{~min}$, and the OD was measured at $360 \mathrm{NM}$ by using a spectrophotometer. Potassium sulfate was used as a standard. Percentage of Sulphate content present in the sample was calculated by using this formula,

$$
\begin{aligned}
& \text { Sulfate content of } \\
& \text { the sample }(\%)
\end{aligned}=\frac{\text { OD of the sample }}{\frac{\text { OD of the standard }}{\text { Weight of the sample }}}
$$

\section{Galactose content}

It was determined by a colorimetric method using Anthrone reagent Yaphe et al. 1960 [23] and galactose was used as a standard. Anthrone reagent was prepared by dissolving $200 \mathrm{mg}$ of reagent in $100 \mathrm{ml}$ of $83.6 \%$ sulfuric acid and stored at $4{ }^{\circ} \mathrm{C}$ for further use. In this $1 \mathrm{ml}$ of sample mixed with Anthrone reagents $(10 \mathrm{ml})$ and heated in a boiling water bath for about $11 \mathrm{~min}$. The tube was then cooled and kept in an ice bath. The absorbance is taken at $630 \mathrm{~nm}$.

\section{Statistical analysis}

All the outcome was summarized by mean $\pm S D$ and statistical significance was estimated by one-way analysis of variance (ANOVA) using SPSS (version 16) program followed by LSD.

\section{RESULTS AND DISCUSSION}

\section{Phytochemical}

Seaweed contributes to its efficacy as nutraceutical and traditional medicine based on the presence of their chemical components. Some factors like climatic condition, season, species, subspecies, harvest and the method used for extraction of compounds will devastate the chemical compositions of the extract [24]. Seaweeds are primitive non- 
flowering plants without roots, stems, and leaves. They contain different vitamins, minerals, trace elements, proteins and bioactive substances [25]. In our present study, five different extract methanol and aqueous extract exhibited the highest number of compounds whereas ethanol and chloroform are having the least possible number of phytochemical compounds. The presence of photochemical in different solvents Methanol (table 2), Aqueous (table 3), Ethanol (table 4) and chloroform (table 5). An alkaloid, flavonoids are having various medicinal properties and detected in the extracts are compounds that have been documented to possess a variety of medicinal properties and health-promoting effects. Alkaloids were absent in all the selected seaweeds; Phenols found to be plentiful as reported by Wang et al. 2013 [21]. The preliminary qualitative test shows the presence of tannins, betacyanin, flavonoid, terpenoid, betacyanin, carbohydrate, protein and phenol in methanol extract in most of the seaweed. Glycoside, cardiac glycoside, and quinone are present in some seaweeds of ethanol extract. Saponin is present in D. delicatula, and it is used for their ammonia emissions in animal feeding. Gomathi and Sheba reported that the presence of carbohydrates, protein, Glycosides, Anthraquinones, and Alkaloids in the methanol extract of $U$. reticulate [26].

Table 2: Phytochemical content of underexploited seaweeds in methanol extract

\begin{tabular}{|c|c|c|c|c|c|}
\hline \multirow[t]{2}{*}{ Phytochemical } & \multicolumn{5}{|c|}{ Methanol extract } \\
\hline & P. gymnospora & D. delicatula & A. spicifera & U. faciata & P. hornemannii \\
\hline Alkaloid & - & - & - & - & - \\
\hline Saponins & + & + & - & + & + \\
\hline Tannins & + & + & + & + & + \\
\hline Phlobatannins & + & + & - & - & + \\
\hline Flavonoids & + & + & + & + & + \\
\hline Steroid & + & + & + & + & - \\
\hline Terpenoids & + & + & + & + & + \\
\hline Glycoside & - & - & + & - & \\
\hline Cardiac Glycosides & - & - & + & + & - \\
\hline Phenolics & + & + & - & + & - \\
\hline Quainones & - & + & + & - & + \\
\hline Carbohydrate & + & + & + & + & + \\
\hline Protein & + & + & + & + & + \\
\hline Betacyanin & - & + & - & + & + \\
\hline Cumarin & - & - & - & - & - \\
\hline
\end{tabular}

$\mathrm{n}=3$; +indicates presence; -indicates absence

Table 3: Phytochemical content of underexploited seaweeds in the aqueous extract

\begin{tabular}{|c|c|c|c|c|c|}
\hline \multirow[t]{2}{*}{ Phytochemical } & \multicolumn{5}{|l|}{ Aqueous extract } \\
\hline & P.gymnospora & D. delicatula & A. spicifera & U. faciata & P. hornemannii \\
\hline Alkaloid & - & - & - & - & - \\
\hline Saponins & - & + & - & - & - \\
\hline Tannins & + & - & + & + & - \\
\hline Phlobatannins & - & - & - & - & - \\
\hline Flavonoids & + & - & + & + & + \\
\hline Steroid & + & + & + & - & - \\
\hline Terpenoids & + & - & - & + & + \\
\hline Glycoside & + & - & + & - & - \\
\hline Cardiac Glycosides & + & - & + & - & - \\
\hline Phenolics & + & - & + & - & - \\
\hline Quainone & + & + & - & - & + \\
\hline Carbohydrate & - & - & + & + & - \\
\hline Protein & + & + & + & + & + \\
\hline Betacyanin & - & - & - & + & - \\
\hline Cumarin & - & + & - & - & - \\
\hline
\end{tabular}

$\mathrm{n}=3$; +indicates presence; -indicates absence

Table 4: Phytochemical content of underexploited seaweeds in Ethanol extract

\begin{tabular}{|c|c|c|c|c|c|}
\hline \multirow[t]{2}{*}{ Phytochemical } & \multicolumn{5}{|l|}{ Ethanol extract } \\
\hline & P.gymnospora & D. delicatula & A. spicifera & U. faciata & P. hornemannii \\
\hline Alkaloid & - & - & - & & - \\
\hline Saponins & - & + & - & - & + \\
\hline Tannins & + & + & + & - & + \\
\hline Phlobatannins & - & - & - & - & - \\
\hline Flavonoids & + & - & + & - & - \\
\hline Steroid & - & - & - & - & + \\
\hline Terpenoids & + & + & - & - & + \\
\hline Glycoside & + & - & + & - & - \\
\hline Cardiac Glycosides & + & - & + & - & - \\
\hline Phenolics & + & - & - & - & - \\
\hline Quainone & + & + & + & - & + \\
\hline Carbohydrate & - & - & - & - & - \\
\hline Protein & + & + & + & + & + \\
\hline Betacyanin & - & - & + & + & - \\
\hline Cumarin & - & + & - & - & - \\
\hline
\end{tabular}

$\mathrm{n}=3$; +indicates presence; -indicates absence 
Table 5: Phytochemical content of underexploited seaweeds in Chloroform extract

\begin{tabular}{|c|c|c|c|c|c|}
\hline \multirow[t]{2}{*}{ Phytochemical } & \multicolumn{5}{|c|}{ Chloroform extract } \\
\hline & P.gymnospora & D. delicatula & A. spicifera & U. faciata & P. hornemannii \\
\hline Alkaloids & - & - & - & - & - \\
\hline Saponins & + & + & - & - & + \\
\hline Tannins & + & - & + & + & + \\
\hline Phlobatannins & - & - & - & + & - \\
\hline Flavonoids & + & - & + & - & + \\
\hline Steroid & + & + & + & - & - \\
\hline Terpenoids & + & - & - & - & + \\
\hline Glycosides & + & - & + & - & - \\
\hline Cardiac Glycosides & + & - & + & - & - \\
\hline Phenolics & + & - & - & - & - \\
\hline Quanoin & + & + & + & + & + \\
\hline Carbohydrate & - & - & + & - & + \\
\hline Protein & - & - & + & - & + \\
\hline Betacyanin & + & - & + & + & - \\
\hline Cumarin & - & - & - & + & + \\
\hline
\end{tabular}

$\mathrm{n}=3$; +indicates presence; -indicates absence

\section{Biochemical and antioxidant activity}

The qualitative analysis of phytochemical investigation revealed the presence of carbohydrates, protein, and phenols in all selected seaweeds. Among the five seaweeds, the carbohydrate was varied from 50.6 to $\%$ of dry weight to $26 \%$ dry weight showed a high carbohydrate content than other seaweeds was reported by Roy and Anantharaman 2017 [24]. Nguyen et al. 2011[27] reported that high carbohydrate content $(64.00 \%$ dry weight) present in Caulerpa lentillifera, Similarly, we have a high percentage of carbohydrate in P. hornemannii (51.2 $\pm 0.78 \%$ ) and A. spicifera (45.4\%). Quantitative analysis of protein content ranged from $28.5 \%$ and $4.4 \%$. Dhargalkar et al. 1986 [28] reported that proximate biochemical composition of some seaweed from Mandapam which revealed that $P$. gymnospora contained maximum protein (17.08 $\pm 0.28 \%)$ including Enteromorpha intestinalis $(16.38 \pm 0.50 \%)$ and Sargassum tenerimum $(12.42 \pm 0.63 \%)$. In this present study protein content of the P. gymnospora was $25.7 \pm 0.89 \%$ of dry/wt. of the seaweeds. Higher protein content was found in the brown seaweed T. ornate and lower in the red seaweed $G$. verrucosa reported by Parthiban $e t$

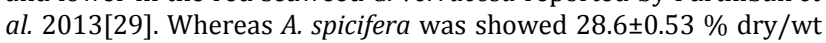

high amount of protein content. Similarly, Dinesh et al. 2007[30] recorded highest protein content in brown alga Tubinaria ornate from Gulf of Mannar region, and Selvi et al. 1999[31] reported more protein content in red alga Hypnea valentiae. The antioxidant activity seaweed extract was measured using DPPH (2,2-diphenyl-1-picrylhydrazyl-hydrate), hydroxyl radical scavenging; it is a less timeconsuming method when compared to other methods. It is neutralized by single electron transfer (SET) or by hydrogen atom transfer (HAT). The reaction mixture color was slowly changed from purple to yellow, and it is measured by spectrophotometer [32-33]. The scavenging activity of methanol extract compared with the standard Gallic acid. At $5 \mathrm{mg} / \mathrm{ml}$ concentration P. hornemannii fascinate $18.2 \pm 0.45 \%$ and $A$. spicifera possess $17.1 \pm 0.57 \%$ scavenging activity on DPPH. Whereas Revathi et al. [34] reported that Hypneava lentiae showed $41.22 \pm 0.65 \%$ scavenging activity at $50 \mathrm{mg} / \mathrm{ml}$ concentration. $D$. delicatula showed a high amount of sulfate content followed by P. hornemannii, A. spicifera, U. facita, P. gymonospora [35]. Likewise, galactose, total phenol content and sulfate content of $D$. delicatula showed the best result when compared to other seaweed. The existence and percentage of biochemical and antioxidant level in the selected seaweed were depicted in fig. 1 .

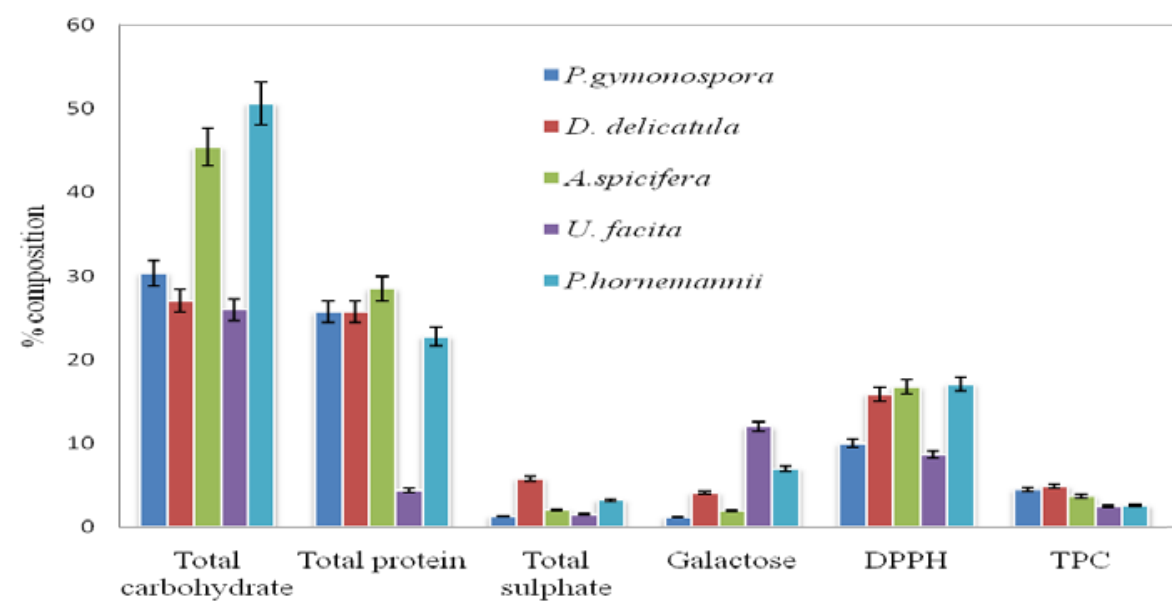

Fig. 1: Biochemical and antioxidant activity and the values are expressed as mean $\pm S D ; n=3$

\section{Antibacterial activity of seaweeds}

Priyadharshini et al.,(2011) [36] have reported that seaweeds are an excellent source of components such as polysaccharides, tannins, flavonoids, phenolic acids, bromophenols, and carotenoids has exhibits different biological activities. Depending upon their solubility and polarity, different solvents shows the different antimicrobial activity. So chemical compounds should be extracted from different seaweeds in order to optimize their antibacterial activity by selecting the best solvent system.

The antimicrobial activity of the methanol crude seaweed extract 
showed a prospective activity against most of the pathogens and it has been portrayed in fig. 2. Methanol have higher antibacterial activity than that of extracts obtained with other organic solvents (Lavany and veerappan, 2011) [37]. Devi et al., 2008 [38] reported that the methanol extract of seaweeds contains phenolics, alkaloids and amino acids which may be responsible for the antimicrobial activity. Earlier reported that ethanol extract of marine seaweed Enteropmorpha compressa, Cladophorosis zollingeri, P. gymnospora, $S$. wightii, and $G$. corticata are active against most of the grampositive and negative bacteria [39]. In this present study, we conclude that methanol extract showed an adequate amount of phytochemical compounds hence it is taken for antimicrobial activity testing. P. gymonospora exhibit maximum activity to $B$. cereus $(2.4 \pm 1.57 \mathrm{~mm})$ and minimum activity against $C$. albicans, $D$. delicatula showed better activity towards $P$. aeruginosa $(2.0 \pm 0.28$ $\mathrm{mm})$ and lower activity against $S$. aureus $(0.8 \pm 1.20 \mathrm{~mm})$, A. spicifera exhibit higher activity on $B$. cereus $(2.3 \pm 0.06 \mathrm{~mm})$ and lower activity on $S$. aureus $(0.5 \pm 1.22 \mathrm{~mm})$, Ulva facita possess better activity towards $P$. aeruginosa $(2.3 \pm 0.28 \mathrm{~mm})$ and least activity against $C$. albicans $(0.9 \pm 2.31 \mathrm{~mm}), \mathrm{P}$. hornemannii showed maximum activity against $B$. cereus $(1.6 \pm 0.4 \mathrm{~mm})$ minimum activity towards $S$. aureus $(1.1 \pm 0.6 \mathrm{~mm})$. Lavanya et al. 2017 [40] state that the least inhibition was observed in methanol and ethanol extract of seaweed. E. coli (3.5 mm), P. putida (2.5 mm), K. pneumonia $(4.3 \mathrm{~mm})$, and $S$. aureus (3.5 $\mathrm{mm}$ ) against Gracilaria sps. In future, this present findings may come as a better potent antibacterial compound.

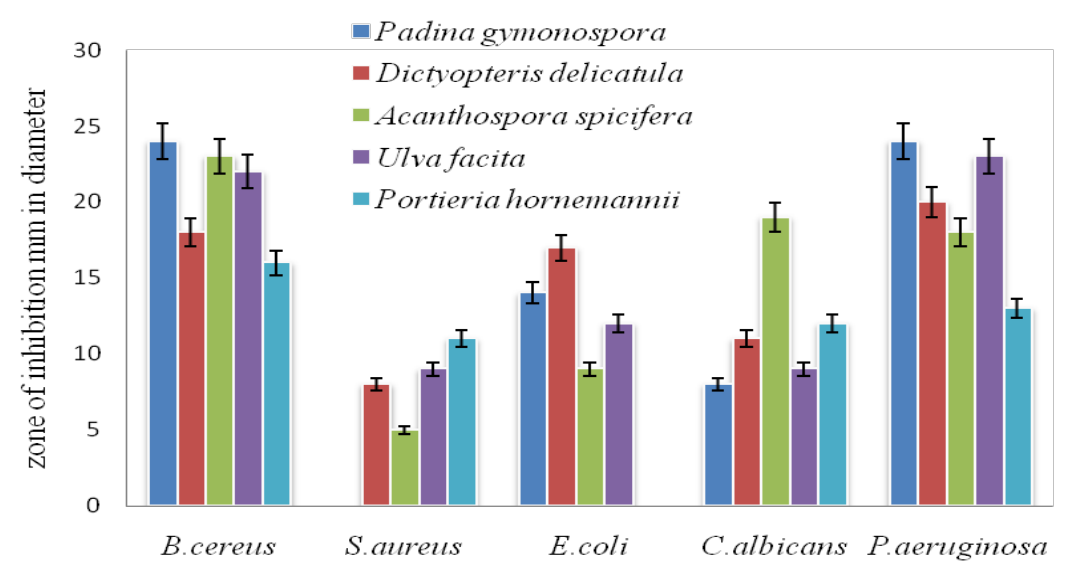

Fig. 2: Antibacterial activity of seaweeds and the values are expressed as mean $\pm S D ; n=3$

\section{CONCLUSION}

The phytochemical and biochemical analysis of these seaweeds has sufficient nutrient supplements such as proteins, carbohydrates, phenol, etc. It has been taken as a feed for cattle and act as a good fertilizer for plant growth, cost-effective nutrient supplement with predominant yield. Also, seaweeds may solve the problems of deficiency of protein, carbohydrate, and mineral deficiency in human nutrition by consuming them in daily life. Further seaweed being a novel candidate in pharmaceuticals to develop a natural compound as an anticancer agent for production. Our results revealed that the marine alga has several chemical constituents of high therapeutic efficacy. Further studies are required to investigate the extracts of for potential pharmacological properties.

\section{ACKNOWLEDGMENT}

The authors are grateful to the Science and Engineering Research Board (SERB-Early Career Research Award-ECR/2015/000460), Government of India, New Delhi for the financial support and also thanks to the Management of Sathyabama Institute of Science and Technology (Deemed University) Chennai for the providing the Infrastructure facility.

\section{AUTHORS CONTRIBUTIONS}

R. T. has designed, directed the study and co-wrote the paper; M. S. performed the experiments, interpreting the results and worked on the manuscript; J. J. helped in paper writing and correction. All authors discussed the results and commented on the manuscript.

\section{CONFLICT OF INTERESTS}

\section{Declared none}

\section{REFERENCES}

1. Carte BK. Biomedical potential of marine natural products: marine organisms are yielding novel molecules for use in basic research and medical applications. Bioscience 1996;46:271-86.

2. Ahilan B, Sujathkumar NV. Seaweed is it really useful. Seafood Export J 1990;22:23-5.
3. Bharathan G. Experimental culture of Gracilaria at the mariculture centre, Muttukadu, Tamil Nadu. J Mar Biol Assoc India 1987;29:54-9.

4. Burrows EM. Seaweeds of the British Isles: Chlorophyta. Nord J Bot; 1991.

5. Mishra VK, Temelli F, Ooraikul B, Shacklock PF, Craigie JS. Lipids of the red alga Palmaria palmate. Bot Mar 1993;6:169-74.

6. Rizvi M, Shameel M. Studies on the bioactivity and elementology of marine algae from the coast of Karachi, Pakistan. Phytother Res 2004;18:865-72.

7. Hameed A, Vohra S. Indian system of medicine skin diseases (A herbo mineral Approach), New Delhi, India. CBS Publishers 2001. p. 174.

8. Keyrouz R, Abasq M, Le Bourvellec C, Blanc N, Audibert L, ArGall E, et al. Total phenolic contents, radical scavenging and cyclic voltammetry of seaweeds from Brittany. Food Chem 2011;126:831-6.

9. Rodríguez Montesinos YE, Arvizu Higuera DL, Hernandez Carmona G. Seasonal variation on size and chemical constituents of Sargassum sinicola setchellet gardner from bahía de la paz, baja california sur. Mexicol Phycol Res 2008;56:33-8.

10. Tulay A, Fusun S. Riza antimicrobial activities of some marine algae and some cyanobacteria from çanakkale (Turkey). J Algal Biomass Utilisation Br J Pharmacol 2013;4:35-40.

11. Demirel Z, Yilmaz Koz FF, Karabay Yavasoglu UN, Ozdemir G, Sukatar A. Antimicrobial and antioxidant activity of brown algae from the Aegean Sea. J Serb Chem Soc 2009;74:619-28.

12. Chakraborty C, Hsu CH, Wen ZH, Lin CS, Agoramoorthy G. Zebrafish: a complete animal model for in vivo drug discovery and development. Curr Drug Metabol 2009;10:116-24.

13. Chandran M, Vivek P, Kesavan D. Phytochemical screening and anti-bacterial studies in salt marsh plant extracts (Spinifexlittoreus (BURM. F) MERR. and Heliotropium curassavicum L.). Int J Chemtech Res 2014;6:4307-11.

14. Indumathi C, Durgadevi G, Nithyavani S, Gayathri PK. Estimation of terpenoid content and its antimicrobial property in Enicostemmalitorrale. Int J ChemTech Res 2014;6:4264-7. 
15. Hassan A, Hawa S, Bakar A, Fadzelly M. Antioxidative and anticholinesterase activity of Cyphomandrabetacea fruit. Sci World J 2013:7. http://dx.doi.org/10.1155/2013/278071

16. Singh D, Singh P, Gupta A, Solanki S, Sharma E, Nema R. Qualitative estimation of the presence of a bioactive compound in Centella Asiatica: an important medicinal plant. Int J Life Sci Med Sci 2012;2:4-7.

17. Wadood A, Ghufran M, Jamal SB, Naeem M, Khan A, Ghaffar R. Phytochemical analysis of medicinal plants occurring in local area of Mardan. Biochem Anal Biochem 2013;2:1-4.

18. National Committee for Clinical Laboratory Standards. Reference method for broth dilution antifungal susceptibility testing of yeast. Approved standard M27-A. PA: National Committee for Clinical Laboratory Standards Wayne; 1997.

19. Magaldi S, Mata Essayag S, De Capriles CH, Perez C, Colella MT, Olaizola $\mathrm{C}$, et al. Well diffusion for antifungal susceptibility testing. Int J Infect Dis 2004;8:39-45.

20. Wang T, Jonsdottir R, Olafsdottir G. Total phenolic compounds, radical scavenging and metal chelation of extracts from Icelandic seaweeds. Food Chem 2009;116:240-8.

21. Wang X, Wu Y, Chen G, Yue W, Liang Q, Wu Q. Optimisation of ultrasound-assisted extraction of phenolic compounds from sparganiirhizoma with response surface methodology. Ultrason Sonochem 2013;20:846-54

22. Dodgson KS, Price RG. A note on the determination of the ester sulphate content of sulphated polysaccharides. Biochem J 1962;84:106

23. Yaphe W. Colorimetric determination of 3, 6-anhydrogalactose and galactose in marine algal polysaccharides. Anal Chem 1960;32:1327-30.

24. Roy S, Anantharaman P. Biochemical compositions of seaweeds collected from Olaikudaand Vadakkadu, Rameshwaram, Southeast Coast of India. J Marine Sci Res Dev 2017;7:2.

25. Dharmesh R, Stalin K, Ramavatar M, Siddhanta AK. Antioxidant activity and phytochemical analysis of a few Indian seaweed species. Indian J Geomarine Sci 2014;43:507-18.

26. Gomathi K, Anna Sheba L. Phytochemical screening and heavy metal analysis of Ulva reticulata. Asian J Pharm Clin Res 2018;11:84-8

27. Nguyen VT, Ueng JP, Tsai GJ. Proximate composition, total phenolic content, and antioxidant activity of seagrape (Caulerpalentillifera). J Food Sci 2011;6:950-8.
28. Dhargalkar VK. Biochemical studies in Ulva reticulate Forskal. Mahasagar 1986;19:45-51.

29. Parthiban C, Saranya C, Girija K, Hemalatha A, Suresh M Anantharaman P. Biochemical composition of some selected seaweeds from Tuticorin coast. Adv Appl Sci Res 2013;4:362-6.

30. Dinesh G, Sekar M, Kannan R. Nutritive properties of seaweeds of gulf of Mannar, Tamil Nadu. Seaweed Res Utiln 2007;29:12532 .

31. Selvi M, Shakila P, Selvaraj R. Studies on biochemical contents of macro-algae from cuddalore and Thirumullaivasal estuaries of Tamil Nadu. Seaweed Res Utiln 1999;21:99-103.

32. Huang D, Ou B, Prior RL. The chemistry behind antioxidant capacity assays. J Agric Food Chem 2005;53:1841-56.

33. Baskaran K, Pugalendi KV, Saravanan R. Free radical scavenging activity of ethyl acetate extract of cardiospermum halicacabum by in vitro assays. Am J Mol Biol 2014;2:300-8.

34. Revathi D, Baskaran K, Subashini R. Antioxidant and free radical scavenging capacity of red seaweed Hypneavalentiae from Rameshwaram coast Tamil Nadu, India. Int J Pharm Pharm Sci 2015;8:232-7.

35. Alves MG, Dore CM, Castro AJ, do Nascimento MS, Cruz AK, Soriano EM, et al. Antioxidant, cytotoxic and hemolytic effects of sulfatedgalactans from edible red alga Hypneamusciformis. J Appl Phycol 2012;24:1217-27.

36. Priyadharshini S, Bragadeeswaran S, Prabhu K, Ran SS. Antimicrobial activity and hemolytic activity of seaweed extracts Ulva fasciata (Delile 1813) from Mandapam, Southeast coast of India. Asian Pacific J Trop Biomed 2011;1:S38-S39.

37. Lavanya R, Veerappan N. Antibacterial potential of six seaweeds collected from gulf of mannar of Southeast Coast of India. Adv Biol Res 2011;5:38-44.

38. Devi GK, Manivannan K, Thirumaran G, Rajathi FAA, Anantharaman P. In vitro antioxidant activities of selected seaweeds from the southeast coast of India. Asian Pacific J Trop Med 2011;4:205-11.

39. De Campos Takaki GM, Diu MB, Koening ML, Pereira EC. Screening of marine algae from Brazilian northeastern coast for antimicrobial activity. Bot Mar 1988;31:375-8.

40. Lavanya R, Fazina M, Kajal C, Lokanatha V. Phytochemical evaluation and antimicrobial activity of Gracilaria opuntia: an important anti-diabetic red marine macroalgae. Int J Curr Pharm Res 2017;9:37-41. 